\title{
The posting of workers in the European road transport industry: An approach based on the discourses of social and institutional stakeholders
}

\author{
Alberto Riesco-Sanz \\ Universidad Complutense de Madrid/Instituto TRANSOC, Spain \\ Jorge García López \\ Universidad de Castilla-La Mancha, Spain \\ María del Mar Maira Vidal \\ Universidad Complutense de Madrid/Instituto TRANSOC, Spain
}

\begin{abstract}
The posting of workers is a challenge for the (national) regulatory and job protection frameworks currently in effect in the European Union. Based on the specific case of road transport, this article analyses the discourses of the principal social and institutional stakeholders (trade unions, employers' associations, European institutions and the labour inspectorate) and identifies the controversies that have arisen around the definition, regulation and assessment of worker posting and, in general, the direction in which the European unification project is heading.
\end{abstract}

\section{Keywords}

Social Dumping; Posting of Workers; European Union Integration; Road Haulage; Posted Workers Directive

\section{Introduction}

The creation of a single internal market has played (and still plays) a key role in the European project. In relation to the free circulation of workers, the unified market has involved the contact, simultaneous action and coordination of a wide range of very different stakeholders and regulatory and institutional frameworks (starting with national Social Security systems). The lex loci laboris principle, or the principle of applying the law of the country in which a worker carries out their activity, has been a determining factor in this coordination effort, clarifying the ground rules for those (increasingly frequent) situations involving different regulatory and institutional frameworks. Nevertheless, since the beginning of the 1970s, the European regulation which coordinates the different national Social Security systems has also recognised the existence of an exception to the application of this general principle, namely the temporary posting of workers between the different Member States. To the legislator's mind, the brief duration of these postings (up to a maximum of 12 months, subsequently extended to 24 and then, more recently, reduced to 18) justifies the nonapplication of the lex loci laboris principle. Under such circumstances, posted workers remained linked to the welfare system and institutional framework of their country of origin during the entire duration of their posting.

In the European context, in which the establishment of a single internal market has done little to close the enormous gap which exists between countries as regards social and labour standards and costs, the recognition of this exception to the lex loci laboris principle is by no means innocuous and the increased prevalence of the posting of workers in Europe over recent decades is therefore hardly surprising. From the end of the 1980s onwards, it became apparent that many firms were using the transnational subcontracting of companies and workers as a means of sidestepping legislative issues and labour costs in their countries of origin (Bernaciak, 2014). The posting of workers, initially conceived as an exceptional situation in the mobilisation and use of the labour 
force, thus became a recurring practice in certain sectors of the European labour market. It is a means of mobilising the labour force that national Social Security systems felt unable to control and which generated a large amount of concern among some of Europe's social and institutional stakeholders (due to its potential impact on the labour market and local bushiness fabric, as well as to the proliferation of fraudulent and abusive practices, etc.). After a difficult and laborious process (Cremers, 2016b), these concerns eventually gave rise to the approval in 1996 of the Posting of Workers Directive (Directive 96/71/EC). This directive, initially conceived as part of the European Union's drive towards social development, aimed to reconcile freedom of movement and the provision of services with the protection of workers' basic social rights (Cremers et al., 2007).

Nevertheless, the directive's inherent limitations (for example, it failed to foresee the deeprooted impact that the Eastern enlargement of 2004 would have on the labour market), along with the restricted interpretation of the document in recent years by the European Commission (Cremers, 2016b) and the EU Court of Justice (Lalanne, 2011), have weakened the efficacy of the 1996 Posting of Workers Directive as a mechanism for regulating and protecting posted workers in Europe (Bernaciak, 2014; Cremers et al., 2007; Wagner \& Lillie, 2014). This has given rise to a succession of proposals for expanding and reviewing the directive, with the following results: i) the approval of the 2014 Enforcement Directive (Directive 2014/67/EU), which aimed to fill in some of the gaps and resolve some of the difficulties detected in relation to the enforcement of the 1996 Directive (Páramo Montero, 2015); and ii) the revision of the directive approved in 2018 (Directive 2018/957 with transposition expected in 2020), which aims to implement the principle of equal pay beyond the minimum wage (thereby forcing employers to take into consideration all other supplementary salary items that are generally applied to the local workforce) and increase the number of (general efficacy) collective agreements that apply to all posted workers (European Parliament and Council of the European Union, 2018). ${ }^{1}$

More than the final outcomes in the form of legal documents, what is of particular interest to us in relation to these reformulation and debate processes is that they clearly indicate that the posting of workers is a hotly disputed issue in the field of European labour relations. It is also an issue that involves many different stakeholders (trade unions, employers' associations, States, the labour inspectorate and European institutions, etc.) with a wide range of diagnoses, claims and proposals. It is a topic which generates much tension regarding what exactly are the most pressing concerns of the European project, as well as the current course charted by the world of work and the actions that this necessitates. We refer, for example, to the tensions which exist between transnational economic dynamics and national institutional architectures (aimed at regulating and protecting labour); to the impact of the establishment of a European labour market with no regulatory framework or common labour standards; to the tension resulting from the often complicated coexistence of social and economic principles in the European project; and to the disputes arising between different sectors of European capital, which cannot always be interpreted from a national perspective, etc. Aspects of all these different issues are present (some more explicitly, some less so) in the phenomenon of worker posting.

The present article aims to explore and identify these tensions and differences in relation to the road transport industry, by analysing the discourses of the principal European social and institutional stakeholders. These discourses were prompted by the European Commission's announcement in March 2016 of its plan to review the 1996 Directive, a process which culminated (barring any further developments) in the approval of Directive 2018/957 in June 2018. In order to do this, the initial sections will explore the importance of worker posting in Europe and provide some details of the fieldwork carried out. The article will then analyse the discourses used by the principal social and institutional stakeholders regarding the current posting of worker regulation, whether or not it can be applied to the road transport industry and the nature and impact of social dumping on that industry. We shall also explore how the diagnoses and interventions proposed by certain stakeholders vary significantly in accordance with the likelihood of those they represent 
This is a previous version of the manuscript published in European Journal of Industrial Relations, 29 June 2019 - OnlineFirst. https://doi.org/10.1177/0959680119860721

being able to benefit from the increasing disassociation between wealth generation processes and national regulatory frameworks. The article finishes with some general conclusions which aim to locate the debate on the posting of workers within a broader discussion of the challenges facing the world of work today.

\section{The phenomenon of posted workers in the European Union (EU) and its significance.}

The posting of workers constitutes a specific type of labour force mobility linked to the principle of the free provision of services recognised by the EU. Although the statistical sources which currently exist for measuring the posting of workers (A1 forms completed by companies posting their employees) have tended to underestimate the dimensions of this practice (Cremers, 2011; European Commission, 2016; Mussche et al., 2018; Voss et al. 2016), it is clear that it is a growing phenomenon, with the number of posting authorisations issued rising from 1.2 million in 2010 to 2.8 million in 2017 (De Wispelaere and Pacolet, 2019). The increase recorded, however, does not change the fact that the posting of workers is still (statistically speaking) a phenomenon that affects only a small minority at a European-wide level. Its significance lies in the global challenge that this workforce mobilisation model would pose to labour relations overall in the event of it becoming general practise. ${ }^{2}$

As explained above, the posting of workers presupposes that posted workers maintain labour ties with their country of origin, and given that their posting is temporary, assumes that they will continue to pay into and be covered by the Social Security service in effect in that country. EU regulations on the posting of workers state that all posted workers should be subject to the same conditions as local workers as regards a series of protection standards covering minimum wage, rest and work periods, paid holidays, equal rights and non-discrimination, health and safety, etc. (European Commission, 2013: 2). Despite this, however, in a context such as the European Union, characterised by increasingly complex remuneration systems and the uneven development of social welfare systems, in practice, having recourse to posted workers enables companies to drastically reduce labour costs, with savings of between $20 \%$ and $30 \%$ (or even $50 \%$ on occasions) according to available estimates (Berntsen and Lillie, 2015; Cremers, 2011: 29; European Commission, 2016: 76-81; Voss et al. 2016: 37). The enforcement in 2020 of the revised Posting of Workers Directive, approved in 2018, will probably help reduce these differences by ensuring equal pay for all posted workers, beyond the minimum wage. As mentioned above, the new directive obliges employers to take other pay supplements into account (seniority, Christmas bonuses, etc.), providing they are generally applied. It also clarifies the question of travel, board and lodging expenses, which are often used by many companies to considerably reduce the income of posted workers. Nevertheless, these measures do not eliminate the drastic differences which exist within the EU in terms of social contributions, meaning that variations in labour costs will persist (albeit to a slightly lesser extent), and with them the advantages (and risks) of labour force mobilisation in countries with higher labour standards.

The presence of posted workers (particularly in sectors such as the construction and transport industries) has also triggered a certain degree of concern among some employers (mainly those whose operations are based on mobilising the local workforce) and, above all, the trade unions, which see the systematic mobilisation of posted workers as a kind of 'social dumping' which depresses both salaries and working conditions for all concerned. Moreover, the posting of workers is often seen as being linked to irregular practices (letterbox companies, false postings, etc.), which in turn foster unfair competition between companies, as well as the abuse and violation of the basic rights of posted workers (Bernaciak, 2014; Cremers, 2011, 2014; Dølvik and Eldring, 2006; Krings, 2009; Muller, 2014; Wagner and Lillie, 2014). In addition to all this, it is also 
important to bear in mind that attempts by national stakeholders (States, trade unions) to act in relation to this phenomenon have frequently been penalised by the European institutions (European Commission and EU Court of Justice) (Cremers, 2010, 2011; Cremers et al., 2007; Lalanne, 2011), thereby weakening what seemed at one time to constitute the basic foundation of labour relations regulation and protection in Europe, namely the regulatory and institutional framework of the nation-state. Given this situation, it is hardly surprising that the posting of workers is today a source of confrontation between different stakeholders, interests and visions of what the European project should look like. It is a dispute stemming not so much from the current situation, but rather from fears (or ambitions) regarding what the phenomenon may become in the future, and the implications of a possible rise in a certain type of mobilisation and workforce use model within the EU.

The majority of studies carried out to date on the posting of workers have focused on the construction industry (Caro et al., 2015; Cremers, 2006, 2016a; Cremers et al., 2007; Danaj and Sippola, 2015; Druker and Dupré, 1998; Jorens, 2008; Lillie, 2012; Wagner, 2014; Wagner and Lillie, 2014; Woolfson and Sommers, 2006), which has a relatively high concentration of posted workers. ${ }^{3}$ It is also an industry in which, for decades now, the main stakeholders have been protesting against the challenges posed by this method of using the workforce, and have played a key role in the development of current EU regulations (Cremers, 2011). Nevertheless, other sectors in which the presence of posted workers also has a major impact have been the subject of very little research. This is the case with the road transport industry, in which not only are recorded worker posting rates very high (18\% of all the authorisations issued in 2017) (De Wispelaere and Pacolet, 2019: 51-52), but there is also a high proportion of unregistered postings. Moreover, there is a strong presence in this sector of so-called letterbox companies, i.e. businesses which do not actually engage in any transport activities in the country in which they are registered, but rather simply provide cheap labour to companies located in countries with higher operating costs. Despite this, however, until the recent approval of the 2018 Directive, the road transport industry had been excluded from the worker posting regulations (with the exception of cabotage), a situation which has triggered widespread mobilisation among trade union organisations, partially supported by other stakeholders also, including some Member States and certain sectors of the European Parliament and the European Commission, which are in favour of reforming the worker posting regulations and fully applying them to the transport industry. This mobilisation has also given rise to a significant degree of confrontation between these stakeholders and employers' associations regarding the regulation and meaning of worker posting and, in general, the direction in which the European project is heading. All this makes the road transport industry an ideal scenario for the purposes of this article, which is why our analysis focuses on this field.

\section{Methodology and design of the fieldwork}

The results presented in this article form part of a broader research project (mainly focused on the legal field) which aims to analyse how the posting of workers is regulated within the transport industry (Fotinopulos, 2017). The team of sociologists responsible for this project aims to map not only the empirical dimensions of the phenomenon, but also the main challenges and tensions linked to the posting of workers in the EU. It is therefore a preliminary piece of sociographic research aimed at structuring the frameworks, data and discourses available in preparation for subsequent sociological analyses. To this end, alongside other approaches (exploration and use of the different bibliographical and statistical sources available, analysis of actions carried out by the Spanish Labour Inspectorate services in relation to worker posting, etc.), an exploratory qualitative study was conducted comprising in-depth interviews with 12 key informants representing some of the most relevant organisations and institutions in this field: trade unions, employers' associations, labour inspectorate and European institutions. 
This is a previous version of the manuscript published in European Journal of Industrial Relations, 29 June 2019 - OnlineFirst. https://doi.org/10.1177/0959680119860721

Table 1. Interviewee profiles

\begin{tabular}{|c|c|}
\hline E1 & $\begin{array}{l}\text { Director of EU relations at the Spanish Confederation of Freight Transport } \\
\text { (Madrid) }\end{array}$ \\
\hline E2 & Technical Director of the International Road Transport Association (Madrid) \\
\hline E3 & $\begin{array}{l}\text { Member of the Road Transport Industry Executive Committee at the } \\
\text { Comisiones Obreras Trade Union (Madrid) }\end{array}$ \\
\hline E4 & $\begin{array}{l}\text { Member of the Road Transport Industry Standing Committee at the Unión } \\
\text { General de Trabajadores Trade Union (Madrid) }\end{array}$ \\
\hline E5 & $\begin{array}{l}\text { Head of the Bizkaia Labour Inspectorate and leader of the Cibeles Project on } \\
\text { the posting of workers and labour inspectorate (Madrid) }\end{array}$ \\
\hline E6 & $\begin{array}{l}\text { Labour Inspector from Girona, former member of the European Commission } \\
\text { Directorate-General for Employment, Social Affairs and Equal Opportunities } \\
\text { and EU liaison for issues relating to the posting of workers (Girona) }\end{array}$ \\
\hline E7 & $\begin{array}{l}\text { Head of Land Transport Policy at the European Commission's Directorate- } \\
\text { General for Mobility and Transport (Brussels) }\end{array}$ \\
\hline E8 & $\begin{array}{l}\text { Member of the Industrial Relations area of the Social Affairs Department of } \\
\text { Business Europe (Brussels) }\end{array}$ \\
\hline E9 & $\begin{array}{l}\text { EU Public Affairs Manager at the European Confederation of Private } \\
\text { Employment Agencies (Brussels) }\end{array}$ \\
\hline E10 & $\begin{array}{l}\text { Deputy General Delegate Head of Social Affairs, EU Road Safety and } \\
\text { Infrastructure at the International Road Transport Union's Permanent } \\
\text { Delegation to the EU (Brussels) }\end{array}$ \\
\hline E11 & $\begin{array}{l}\text { Legal Adviser of the European Trade Union Confederation specialising in } \\
\text { posted workers (Brussels) }\end{array}$ \\
\hline E12 & $\begin{array}{l}\text { Political Secretary / Road Transport, EWCS and Gender Equality at the } \\
\text { European Transport Workers' Federation (ETF) (Brussels) }\end{array}$ \\
\hline
\end{tabular}

The fieldwork was carried out between November 2015 and April 2016 by the researchers involved in the project. Interviews followed a basic script model adapted to the specific profile of each interviewee/organisation. The interviews (which were conducted in Spanish, English and French) were audio-taped and then transcribed. They were subsequently analysed along with the notes taken by the researchers during the interviews and the various documents provided by the interviewees. The aim of the fieldwork was to explore the discourses of the main social and institutional stakeholders regarding the phenomenon of worker posting in Europe, their demands and assessments regarding the changes to the pertinent regulations that were being debated at the time and, in particular, their opinions regarding the possibility of fully applying these regulations to the transport industry. The exercise enabled the research team to identify the different tensions which exist in relation to both the phenomenon of worker posting itself, and the direction and priorities of the European integration project. These tensions and challenges are briefly outlined and discussed in the following sections.

\section{Presentation, analysis and discussion of the empirical material}

The stance adopted by European social stakeholders regarding existing regulations on the posting of workers in the EU 
One of the first sources of dispute detected in the discourse of the social stakeholders interviewed was existing regulations regarding the posting of workers, i.e. whether or not said regulations were sufficient, whether or not they should be reformed and, as outlined in the next section, whether or not they can (or should) be applied to the road transport industry. The stance adopted by the European employers' associations regarding the regulations in effect until the reform approved in 2018 was one of 'moderate satisfaction'. While employer representatives declared themselves to be against some of the elements enshrined in the existing regulations (such as the acknowledgment of a certain degree of shared responsibility in subcontracting chains or the establishment of an open list of requirements for postings which, in their opinion, put companies in a situation of legal insecurity), in general they claimed to feel satisfied with the different regulations, viewing them as compromise documents resulting from a great deal of hard work. From their perspective, the regulations that governed the posting of workers until 2018 were well balanced and enabled the defence of worker rights (e.g. limiting the activities of letterbox companies, and giving States ample room to manoeuvre regarding the regulation of postings and the fight against social dumping) to be combined with the free provision of services by companies. This is how the representatives of the principal European employers' organisations put it:

We are satisfied with the Directive apart from this one chapter, well, one article, which deals with the subcontracting, but, as I said, it's a compromise and as a compromise we believe it's a good text. [E8, Business Europe]

We have the Posting of Workers Directive 1996, which we always say it is appropriate, it is balanced, it is a fair deal, it allows a fair mobility. (...) [And] this Enforcement Directive [of 2014], it might not be ideal, but it is a good basis, and it will help to address certain issues. [E9, European Confederation of Private Employment Agencies]

Thus, in the opinion of European employers' associations, there was no justification whatsoever for trade unions' and other European institutional stakeholders' calls to reopen the debate around the need to reform a set of hard-won regulations, the possible defects of which had (moreover) to large extent been resolved thanks to the approval of the new directive in 2014. In their opinion, reforming a set of regulations that had just been implemented, and which had not yet been in place long enough to enable a proper assessment of their usefulness or possible shortcomings, was both premature and unnecessary.

What we are saying is: give first time to assess in more detail [the impact of the existing regulation] and not change the rules all over again. [E9, European Confederation of Private Employment Agencies]

We are very much worried about the Commission plan to revise the Posting Directive. [E8, Business Europe])

Thus, the debate and approval of the new 2018 Directive was not well received by the principal European employers' associations. Measures such as ensuring equal pay for workers beyond the minimum wage have been denounced as an attack on social stakeholders' recognised autonomy to negotiate salary scales. Similar negative reactions have been triggered by attempts to automatically apply general efficacy collective agreements to all posted workers, to establish a maximum duration of 12 or 18 months for postings (which they consider to be insufficient in certain sectors) and to apply the Posting Directive to the transport industry, beyond cabotage (BusinessEurope, 2018a). In addition to this specific criticism, employers' associations also see the new directive as a bad agreement which, in their opinion, is more a reflection of the political 
interests of certain countries (in which protectionist measures have been imposed as a response to distorted debates about the effect of the posting of workers) than the manifestation of a sincere will to find solutions to the needs of posted workers (BusinessEurope, 2016, 2018b). For European employers' associations, the posting of workers constitutes a fundamental tool for ensuring business competitiveness, the correct functioning of the single market and, in short, European prosperity. They consider the problems associated with this phenomenon to be limited to certain illegal practices which should be prosecuted. From this perspective, the new directive is not the best solution and, moreover, constitutes a major obstacle for European companies wishing to take advantage of the possibilities offered by the posting of workers (which they believe could have the undesired effect of increasing the prevalence of these illegal practices).

In the eyes of the main trade union organisations, however, the regulations governing the posting of workers were clearly insufficient for defending worker rights. The 1996 Directive was severely constrained as the result of the EU Court of Justice and the European Commission's restrictive interpretation of its content (prioritising the principle of the free provision of services by companies over other considerations, turning the list of minimum employment standards for which posted workers should receive equal treatment into a list of maximum standards that cannot be extended by States, restricting trade union rights to collective action in the field of worker posting, etc.) (Cremers, 2011; Lalanne, 2011; Wagner and Lillie, 2014). Dissatisfaction with these constraints was reflected in a series of different unilateral initiatives launched by those Member States most concerned about the posting of workers, as well as in the approval of the 2014 Directive, which aimed to address some of the shortcomings of the 1996 document (Fotinopulos, 2017).

Despite these steps, however, union representatives were extremely critical of both these and other reform proposals, considering them insufficient and overly ambiguous as regards the principle of equal pay (which was stated but not accompanied by sufficient recognition of the scope of collective bargaining agreements). Other problems mentioned included the limiting of the maximum possible duration of the posting (which is well over the mean real duration of postings, and in this sense, does nothing to limit existing abusive practices); the insufficient definition of responsibilities in subcontracting (which should, in their opinion, involve the acknowledgement of the principle of joint responsibility and solidarity along the entire subcontracting chain); and the fight against letterbox companies. In relation to this last element, for example, the representative of the European Trade Union Confederation stated that:

The Posting of Workers Directive [of 1996] did not prohibit the phenomenon of letterbox companies. The 2014 Directive introduces some criteria which force national authorities to verify the existence of a true establishment in the country of origin. It establishes some criteria for this verification, but they are very vague, since they give national inspectorates a great deal of leeway, while at the same time strengthening the principle of the domestic market to ensure that controls are not overly restrictive. (...) The fact of the matter is that European law continues to condone the principle underpinning letterbox companies. European company law, for example, does not contemplate the principle of a sole headquarters in Europe. It is perfectly possible for a company to register its corporate headquarters in an EU country in which it does no real business whatsoever. [E11, European Trade Union Confederation]. ${ }^{4}$

Thus, in clear contrast to the stance adopted by the employers' associations, European trade unions have always staunchly argued in favour of reopening the debate on the regulations governing the posting of workers in Europe, particularly as regards the drive to address the most controversial points of the existing legislation. According to trade union representatives, the aim is not only to 'technically' improve the current posting of worker legislation, but also (and above all) to bring about a change of policy within European institutions. The change being sought by trade 
unions would once again prioritise the interests and rights of workers and would avoid what is currently perceived as their subordination to the economic freedoms demanded by companies. While never actually calling the market economy itself into question, union stakeholders nevertheless called for more ambitious economic regulation policies (with the creation of European agencies, mechanisms, indicators and institutions and a return to the lex loci laboris principle, which states that a person employed in the territory of a Member State is subject to the legislation of that State, etc.). The aim would be to redress the balance within the European project between the defence of the freedom and rights of companies and the defence of the freedom and rights of citizens.

Rather than a social welfare instrument, the Posting of Workers Directive is still considered to be a means of ensuring the free circulation of services. (...) Whenever there is a conflict between economic freedom and social norms it is clear that the High Court of Justice prioritises economic freedom. [E11, European Trade Union Confederation]

From this perspective, in general terms, the principal European trade unions (in both the East and the West) view the revised 2018 Directive in a positive light. The new directive explicitly recognises that its aim is to provide legal protection for posted workers, rather than just serve as a regulation mechanism for the transnational provision of services by companies within the single market. This explicit recognition aims to curtail future restrictive interpretations of the regulation by the courts (which in the past have prioritised companies' economic freedom over other considerations). Similarly, European trade unions believe that the new directive (with its proposal to extend the principle of equal pay to posted workers, beyond the minimum wage, and to apply general efficacy collective agreements to all posted workers) constitutes a step forward as regards achieving the principle of 'equal pay for equal work', thereby helping to mitigate the negative effects of so-called social dumping. Obviously, they also expressed their dissatisfaction with some of the elements agreed on in the proposed review (approval of a maximum duration for postings which they consider to be excessive; insufficient measures to fight against letterbox companies and to extend shared responsibility in subcontracting chains; risk of failing to apply many collective bargaining agreements; and failure to guarantee that trade unions in arrival countries can protect the representation rights of posted workers, etc.), but this criticism does not mean they do not view it in a positive light, as indeed is the case among the principal European institutions also (European Trade Union Confederation, 2017, 2018).

\section{The discourse of social stakeholders regarding the application of the regulations governing the posting of workers to the road transport industry}

Our fieldwork also identified a second source of friction, centred around the application of the posting of workers legislation to the transport industry. All stakeholders interviewed acknowledged that this industry is characterised by the constant movement of workers (mainly from Eastern Europe), who cross many different national borders during the course of their activity. Nevertheless, as mentioned above, most road transport activities (except cabotage) have habitually been left out of the legislative framework governing the posting of workers. This has prompted a series of recurrent clashes between trade unions and employers' associations regarding what to call the mobility of transport workers and, in short, the possible application of the posting of workers regulations to that industry.

Trade unions have always been firmly in favour of fully applying the posting of workers directives to the whole road transport industry, believing this to be a fundamental step in the fight against abusive practices and social dumping which, in their opinion, are rife within the sector. In the words of the representative of the principal transport trade union: 
We have good legislation in the road transport industry, but it is not applied. (...) All the measures foreseen in Article 9 [of the 2014 Directive] should be enforced also in the road transport sector. [E12, European Transport Workers' Federation]

The problem, therefore, is not the absence of appropriate legislation (although adjustments may be required), but rather a lack of political will by EU institutions to apply existing regulations to the road transport industry and to do so, moreover, while respecting what is, as the trade unions see it, the original spirit of the Directives, namely to protect and safeguard the rights of posted workers in Europe (and not just the economic freedom of companies). This point emerged very clearly in the stance adopted by the same union representative regarding the controversies that have arisen in relation to the decision made by some countries (such as France) to ban weekly rest periods taken in the cabin of the truck (a measure rejected by the Commission because it would limit the free provision of services by foreign companies):

The Commission says that the law is clear but in fact, there is a written explanation issued by the Commission itself to companies in which it says that, in accordance with the regulations governing rest times and conditions, only shorter rest periods can be taken in the cabin, always providing the driver agrees to this arrangement. This is from 2012, and now the Commission is taking measures against the Member States that are enforcing it. (...) This is an example of the fact that there is no real political will at a European level to do something for this industry, to address the problems which exist from a social perspective. [E12, European Transport Workers' Federation]

According to the trade unions, the law of the country in which the activity takes place should be applied automatically in the transport industry, a move which would involve adjusting salaries in accordance with the countries through which the driver passes and obtaining the relevant permits and posting authorisations. The unions believe that, by definition, all international transport services involve the posting of workers and as such, should be regulated and protected by improved posting of workers legislation. Similarly, workers who provide an international transport service, passing across different borders and through different countries, should be paid in accordance with the minimum wage in effect in those countries for the period in which they remain in them (regardless of the ultimate destination of the transported goods). This is how the representative of the leading Spanish trade union organisation explained it:

Whenever any posted worker arrives in a country in which workers earn more, they should earn that wage, even if they are just passing through. [E3, Comisiones Obreras]

Only by ensuring real equality between the employment and wage standards of Member States will it be possible to prevent the posting of workers within the EU from degenerating into social dumping. Nevertheless, these protection measures must be complemented by other steps, including the establishment of minimum price indexes to avoid unfair competition and abuse by shippers; the control and effective application of other relevant European regulations, such as those which govern driving and rest periods; the creation of transnational mechanisms and institutions to regulate the industry (European transport agency, European labour inspectorate); and the creation of solidarity funds to provide economic compensation to workers affected by the fraudulent activities of letterbox companies, etc. In short, a whole set of measures and mechanisms are required to move beyond the mere application and extension of the regulations governing the posting of workers to the transport industry. 
For their part, representatives of the employers' associations adopted a very different outlook, being firmly against the application of the regulations governing the posting of workers to the road transport industry. In the opinion of the employer representatives, beyond that strictly established in the letter of the law (i.e. cabotage), the regulations should not be applied to road transport. To their mind, the regulations had been designed and formulated on the basis of the specific problems facing specific industries (mainly the construction industry), problems which have little or nothing to do with the specificities of a sector such as the transport industry, which is, by its very nature, mobile and transnational. Given that the international road transport industry necessarily involves the movement of the labour force across different national borders, applying the regulations governing the posting of workers would mean considering all activities and services provided in the sector as postings, which is exactly what the trade unions advocate and to which the employers' associations are openly opposed. Business organisations are even against the term posting of workers being applied legitimately to international transport activities. There are two main reasons for this. Firstly, the strong presence of subcontracting and the informal nature of the industry often make it impossible to establish (as the Posting of Workers Directive requires) a formal direct link between the company contracting the service and the company providing the service. This is how the representative of the leading European road transport employers' organisation explained it:

The real posting, as it is understood in the Posting of Workers Directive, is very rare in road transport. Because there are certain conditions for the driver that have to be fulfilled in order to be posted. (...) There is a lot of subcontracting, there is rarely a direct link between the one that orders the transport and the one who fulfils the transport. (...) Many times it is extremely difficult to apply posting of workers in practice, even to cabotage situations, because normally cabotage is a week long. [E10, International Road Transport Union-IRU]

Secondly, the employers' associations believe that in international road transport activities, drivers pass through different countries on a temporary basis only (sometimes spending only hours or days in each one), and do not actually provide any service in them. The regulations governing the posting of workers are, according to the employers' discourse, designed to regulate the posting of workers for much longer periods, with a greater impact, rather than simple situations of transit or short stays in a foreign country, as is the case in the international road transport industry.

I really find it very difficult to accept that the situation [in the road transport industry] as we are talking now about, would be described as posting. Why? The driver is nowhere posted. I mean, the Posting of Workers Directive was adopted, of course targeting other sectors where the people are normally employed for a long period of time. Like, you know it very well, the construction sector, but for our sector it would be really very difficult to apply. [E10, International Road Transport Union-IRU]

The employers' discourse nevertheless acknowledged that, alongside this continuous and temporary situation of transit, there is also a recurring phenomenon in the road transport industry of worker movement from east to west, a circumstance which involves large numbers of workers regularly remaining outside their countries of origin for weeks at a time in order to provide transport services in Europe. The recognition of this situation did not, however, trigger a significant change in the discourse of the employers' association representatives, who continued to express their conviction that these are simple cases of worker movements between the main offices and subsidiaries of a single business group. While the service provided by these workers certainly does involve crossing different countries and borders, the short duration of their stay is the main 
argument used to refute the idea that what we are dealing with here is a case of worker posting (even though many workers remain outside the country in which they reside and in which they are actually employed for several weeks at a time). This view was expressed by the representative of the European transport employers' association as follows:

We know of course that there are movements of drivers, I will not hide anything, it is mostly of course drivers from the East working in the West, but this is basically mostly not done under the Posting of Workers Directive. It is basically a simple labour contract with the country where they come from, because normally the company would have a subsidiary in that country so they basically exchange drivers on the basis of that. The drivers also they don't stay in the country while they work. They return regularly to their country of residence. So, again, we can't talk about posting here. (...) A Spanish hauler opens a daughter company in Poland, hires Polish drivers through their daughter company in Poland and brings them to Spain. (...) The normal practice is they [the drivers] stay two, three, even four weeks in Spain and then return to Poland, for a week, for example, to be with the family, and return back. Or they are used in Poland for international transport... or they go to Russia, for other operations... So now the question is, where is the driver posted? Is he posted in Spain? In Russia? In Poland? What are the rules that apply? [E10, International Road Transport Union-IRU]

The employers' associations not only consider the idea of applying the regulations governing the posting of workers to the transport industry inappropriate, they also believe it to be unfeasible in practical terms. The continuous crossing of borders involved in the industry would force haulers to calculate different salaries, apply different labour regulations and prepare documents in different languages, etc., all for simple daily and/or weekly work activities. This would involve an enormous amount of supervision by States and labour authorities, as well as a huge administrative effort from companies themselves, which, in the employers' opinion, could result in the collapse of the entire industry.

The stance adopted by the employers' associations was partially shared by the interviewees representing the European Commission's Directorate-General for Mobility and Transport and the Spanish Labour Inspectorate, although certain important nuances were detected. For both institutional stakeholders, the regulations governing the posting of workers that were in effect until the 2018 reform would have been hard to apply to activities other than the aforementioned cabotage. Given that the posting of workers was originally defined on the basis of the characteristics prevalent in the construction industry, both institutional stakeholders coincided in pointing out how hard it would be to find situations of posting in the transport industry that would fully fit the criteria established in the legislation.

Nevertheless, both the Spanish Labour Inspectorate and the Directorate-General for Mobility and Transport expressed certain opinions that differed significantly from the discourse and stance adopted by the employers' associations. Firstly, the representatives from the Spanish Labour Inspectorate stated their support for the creation or consolidation of transnational mechanisms for regulating and controlling the posting of workers. These would include the creation of a European inspectorate, the establishment of a European minimum wage, the use of the Internal Market Information System and the creation of European-wide coordinating bodies similar to the Senior Labour Inspectors Committee, for fighting against fraud in worker postings, etc. For its part, the Directorate-General for Mobility and Transport stated that it would be in favour of revising the existing regulations, in order to take into account the specificities of the industry. The DirectorateGeneral thus acknowledged the impact of the posting of workers on the industry, an impact that, in its opinion, could not be properly regulated or counteracted with the regulations in effect prior to 2018. In the words of the members of the Directorate-General interviewed: 
This is a previous version of the manuscript published in European Journal of Industrial Relations, 29 June 2019 - OnlineFirst. https://doi.org/10.1177/0959680119860721

[The] Posting of Workers Directive does not take into account specificities of international transport and that's why it is not easy to apply to international transport and that's why we are really in a difficult position to say whether or not, and to what extent, it should apply. So, for us, the best would be if the posting of workers is revised considering specificities of international transport: the high mobile workers, etc. [E7, DG Mobility and Transport $\mathrm{CE}]$

\section{Social dumping and the posting of workers in the road haulage industry}

The last of the controversies that will be analysed here is centred around the possible negative consequences of the posting of workers. The road transport industry is characterised by being highly fragmented, with companies being extremely dependent on the customers who demand their services (shippers) (AECOM, 2014). This dependency often means that it is customers who in reality impose the rates and conditions of the transport service, thereby triggering fierce competition between different companies operating in the industry and exerting constant pressure to lower prices (Riesco-Sanz et al., 2018). Faced with this situation, many companies have opted for strategies based on reducing operating costs. These strategies can take many forms, including subcontracting certain activities, incorporating new technologies and transport improvements (more modern and fuel-efficient vehicles, computerised transport service and route management, increasing the size and load capacity of the trailers, etc.) and the coordinated bulk purchase of large quantities of fuel. Nevertheless, the main means by which companies have sought to lower operating costs has been by reducing labour costs, which according to existing estimations (AECOM, 2014: 64-68), account for around one third of all transport operating overheads and which, unlike the other components (fuel prices, taxes, etc.) afford companies much more leeway.

It is precisely this attempt to increase competitiveness by reducing labour costs that is behind the systematic mobilisation of labour from European countries with lower wages and weaker employment standards. ${ }^{5}$ According to the trade unions, this mobilisation sometimes takes place through the offshoring of the company infrastructure to low-labour-cost countries, even though most of the company's activity continues to be concentrated in their countries of origin or other countries with high labour costs. On other occasions, this cheaper workforce is mobilised directly by letterbox firms. In both cases, the direct consequence of these business strategies is the violation of the rights and guarantees of all workers (posted or otherwise) in the industry, through what is known as social dumping.

In Europe there is a whole army of posted drivers, with paltry contracts, who spend months and months outside their home countries under extremely stressful circumstances. We see this as a situation of modern slavery. [E3, Comisiones Obreras]

The phenomenon of letterbox companies is not, however, one that is specific to or the sole responsibility of Eastern European countries. In this sense, according to the trade unions, the fight against these types of companies should not be interpreted in terms of a national confrontation (West against East), in which different labour relations, standards of living and social welfare models (and even conceptions of democracy) clash. Quite the opposite, in fact. What actually underlies this supposed clash or conflict of national interests (in which Western European countries ostensibly seek to defend themselves against the abusive practices of companies from the East) is often nothing more than processes of offshoring and/or subcontracting by Western companies looking to transfer their operations (either wholly or partially) to cheaper countries with fewer guarantees and more compliant labour relations models. In other words, what we have is a conflict 
between the main capital invested in the transport industry: capital of diverse origin but with the hegemony of Western countries, which exploit the unequal process of European integration in order to enhance their own competitiveness. This is how the spokesperson of the principal European transport trade union put it:

The main players responsible for letterbox companies are not necessarily Eastern companies, but rather Western firms seeking to use this ploy to access cheaper labour (...). I believe it is a mistake to assume that Eastern European countries are the main source of unfair competition. [E12, European Transport Workers' Federation]

Representatives of the employers' associations coincide with the trade unions in pointing out that subcontracting, the posting of workers and company offshoring constitute strategies used by transport firms to combat the highly competitive conditions in the industry. These strategies are geared towards containing or reducing operating costs, particularly labour costs. Here is how the representative of the European transport employers' association explained it:

Labour mobility for us it is a major tool how to do the business more effectively and also to lower the cost, I will not hide anything to you, it is important, because if you look at the cost structure of the companies, I mean, regardless of where you come, whether you come from West from East, it is all the same. (...) The only cost that remains that you can work with, is of course social cost, and that is the driver. (...) There is a very hard pressure on the price in the sector, so the companies are looking everywhere how to improve their business, and the labour mobility and the exchange of drivers is one of them. [E10, International Road Transport Union-IRU]

The differences between the two discourses mainly stem from their assessment of the legitimacy of these types of business strategies, as well as in relation to their scope and possible harmful effects. Thus, for employers' associations, company offshoring constitutes a legitimate, legal activity in an economy committed to the free provision of services and the free circulation of goods and capital:

There are undeclared activities which of course are social dumping in a sense that the company doesn't pay social security contribution anyway and doesn't provide minimum wage, do not respect labour standards and so on, [so it] can gain competitive advantage, which is unfair (...). But what I don't like to be seen as social dumping is the difference in the cost structure, because the different companies have different cost structures and the fact that the wage somewhere is a bit lower than the wage somewhere else, doesn't constitute social dumping. [E8, Business Europe]

Thus, unlike that expressed in the trade union discourse, employer representatives disassociate offshoring from social dumping and the phenomenon of letterbox companies, and clearly differentiate between the two types of practices. From their perspective, offshoring and the international posting of workers are legitimate, legal strategies which should be seen as clearly different from other (illegal) practices which (occasionally) occur in the industry:

I believe that in the case of road transport, there is a lot of talk about letterbox companies, but most are simply cases in which the company has relocated in order to take advantage of low-cost labour. [E2, International Road Transport Association-ASTIC] 
It is perfectly legal to create a subsidiary in the East and do transport there, or do transport at home. This is a perfectly legal business operation, there is nothing wrong in it. The problem is of course if you set up a letterbox company. [E10, International Road Transport Union-IRU]

Employers' associations do not, therefore, deny the existence of letterbox companies in the industry, although neither do they believe that their presence is structural (i.e. intrinsically linked to the functioning and dynamics of the sector). Rather, they are convinced that they are isolated cases (which are constantly and excessively exploited by trade unions for their own purposes). In the employers' opinion, these practices are inevitable in a sector as large as the road transport industry, in which there will always be operators who are tempted to break the rules by which the majority abide, thereby harming everyone involved.

What we see is that a few limited cases [of abuse linked to the posting of workers] are being cited, referred to, again and again and again. (...) Actually maybe there might not be many different cases of abuse, but, you know, if you are trying to find the example you will also find the old ones. [E9, European Confederation of Private Employment Agencies]

In short, the international posting of workers (and, more generally, the free circulation of goods, capital and labour) is seen in positive terms by the employers' associations interviewed, who believe that it is only temporarily and in the short term that this type of practice may result in imbalances, tension and harm for European societies. Moreover, in the mid and long term, the posting of workers is seen as vital to guaranteeing the competitiveness of European companies in a globalised economy, as well as, in short, the sustainability of the current level of wellbeing and development of European societies (including the existing social welfare model). From this perspective, employers believe that it makes no sense to link the posting of workers to those phenomena classed as instances of social dumping, as the trade unions do:

There is a lot of benefits to mobility and we are clear on that (...). Perhaps, in a very short term, there might be some pressure on some things, but if you look at the longer term, it is positive (...). If you look at the longer term, it achieves certainly both goals, decent working conditions and free movement, are completely compatible and are supported by each other, rather than being opposite (...). The real question we should ask is 'do we compete at European level or do we compete at global level?' (...) 'Does posting add to competitiveness of Europe or not?' Because we do compete at European level, but the competition which will define our quality of life is at global level. [E8, Business Europe]

\section{Conclusions}

The political space that is the nation-state continues to constitute the principal playing field for the institutionalisation, formal regulation and protection of the world of work in Europe, despite the fact that said 'world of work' constantly overflows that political space. It therefore seems only logical that certain stakeholders and institutions should argue that it must be the regulations and institutional framework of the national-state that assume responsibility for regulating economic activities, as part of the drive to adjust the (transnational) dynamics of contemporary wealth generation processes to the existing (national) institutional framework. Nevertheless, the posting of workers in the EU is, from our point of view, a clear example of the existing clash between (national) institutional frameworks and (transnational) social dynamics. It is an example of the 
difficulties encountered today by national structures when attempting to constrain the dynamics of contemporary capitalism and establish themselves as effective mechanism for protecting workers.

The posting of workers can, in fact, be interpreted as an attempt (fostered by the European institutions themselves) to overcome and (partially) deactivate that institutional labour protection and regulation framework. In doing so, it becomes a source of controversy, embodying many different tensions and encompassing many different (often opposing) visions regarding the priorities of the European project. For example: tensions stemming from the existing (and often explicitly sought) lack of synchrony between the national configuration of labour protection mechanisms and the transnational and/or global dynamics of wealth generation processes. Tensions arising from a clash of interests between companies and workers, as well as from competition between different types of capital, often expressed under the guise of inter-state disputes. Tensions between the different principles jostling to become the cornerstone of the European project (democracy and citizen rights, the social welfare model, company freedom, etc.) and ensure their future pre-eminence (with a clear shift over recent decades towards the pre-eminence of economic freedom over and above all other considerations). Tensions between trade union mobilisation strategies which seek to strengthen existing national protection mechanisms, while at the same time acknowledging the need to extend these mechanisms and institutions to the transnational level (European minimum wage and unemployment benefits, social dialogue and European collective bargaining, European labour inspectorate, etc.). And tensions between (union) demands for coordinated and centralised industrial relations regulation spaces at a European level and the (company-led) drive towards the decentralisation and de-coordination of said spaces. To name but a few.

The issue of the posting of workers therefore embodies a plethora of tensions resulting from the changes currently taking place in Europe, while at the same time revealing the presence of other possible debates. Firstly, the urgent need to move towards a true process of European convergence at a social and labour level, as the only means of tackling the phenomenon of social dumping (and, in short, the progressive deterioration of living standards and the democratic quality of our societies). Secondly, the need to address the possible obsolescence (or at the very least, insufficient nature) of the current institutional employment protection framework, in light of the challenge posed by the growing capacity for the offshoring of capital. Given the lack of viable, sound alternatives, the temptation to call for a return to the regulatory framework of the nationstate is strong, and has indeed often been articulated in political terms over recent decades, all over the world (mainly in 'right-wing' and 'left-wing' formulations). Nevertheless, it is not realistic to expect contemporary capitalism to retreat or withdraw, either of its own volition or due to external pressure. In light of this certainty, it is of course possible to demand the improvement of existing (national) protection systems, since there is definitely much that can be done, but it is also necessary to work in parallel to construct a new transnational institutional framework to protect the rights of workers and citizens. This debate around the hypothetical new 'institutionalisation' of the world of work, adapted to the real functioning of contemporary capitalism, requires the de-nationalisation of access to social rights and guarantees, along with the creation of rights and protection mechanisms which are not subject to the worker's prior incorporation into the political community of a sovereign nation-state.

\section{Acknowledgements}

The authors thank the anonymous referees and Richard Hyman for their comments and suggestions.

\section{Funding}


The author(s) disclosed receipt of the following financial support for the research, authorship, and/ or publication of this article: This study presents the main sociological results of the research project entitled 'Current problems and future perspectives regarding the transnational posting of workers: the case of transport workers' [DER2013-43423-R], led by Olga Fotinopulos and funded by the Spanish Ministry of the Economy and Competitiveness.

\section{Notes}

1. In addition to these elements, the directive review process also had several other outcomes, including: the establishment of a maximum posting duration (12 months, which can be extended to a maximum of 18 in the case of 'long-term postings'); the regulation of the payment of travel, board and lodging expenses to posted workers; the application of the equal treatment principle to posted workers by temp agencies; and the recognition of the applicability of the new Posting of Workers Directive to the road transport industry (although the agreement has temporarily been suspended pending the approval of a series sector-based regulations still under discussion) (European Parliament and Council of the European Union, 2018).

2. In 2017, the total number of A1 authorisations registered barely represented $1.2 \%$ of the working population in the EU ( $0.8 \%$ if we count the number of 'single workers' involved) (De Wispelaere and Pacolet, 2019: 48).

3. In 2017, 46.5\% of posting authorisations issued in the EU under Article 12 of the Basic Regulation (posted with a single destination country) were for the construction industry. In countries such as Germany, Sweden, Finland, Norway, Austria, Iceland, Croatia and Latvia, authorisations for this industry accounted for over $50 \%$ of the total number received under Article 12 (De Wispelaere and Pacolet, 2019: 30 y 32).

4. In April 2018, the European Commission announced a new package of legislative initiatives known as the EU Company Mobility Package. The package aimed to regulate the offshoring of companies within the EU, in order to fight against abusive practices by letterbox firms (contemplating the possibility, for example, of independent experts verifying the existence of real activity in the firm's registered country). Nevertheless, the initiative also proposed to enable companies to be constituted digitally, without the people responsible being physically present (a provision which would limit the control of shell companies) (Vitols, 2018).

5. In 2016, transport firms registered in Eastern European countries were responsible for $61 \%$ of all international road haulage activities in the EU-28. Southern European firms were responsible for $18 \%$, meaning that together, these two regions accounted for almost $80 \%$ of all international transport services provided in the EU (Eurostat, road-gotqtott, 2016).

\section{References}

Aecom (2014) Report on the State of the EU Road Haulage Market. Report. Brussels: European Commission.

Bernaciak M (2014) Social dumping and the EU integration process. Brussels: European Trade Union Institute, Working Paper 2014.06

Berntsen L and Lillie N (2015) Breaking the Law? Varieties of Social Dumping in a Pan-European Labour Market. In Bernaciak M (ed.) Market Expansion and Social Dumping in Europe. London: Routledge, pp. 43-60.

BusinessEurope (2016) Revision of the Posting of Workers Directiva - BusinessEurope position. Position paper. Brussels, 17th May. 
This is a previous version of the manuscript published in European Journal of Industrial Relations, 29 June 2019 - OnlineFirst. https://doi.org/10.1177/0959680119860721

BusinessEurope (2018a) Exemption of international transport operations from posting rules. Public letter. Brussels, 21th June.

BusinessEurope (2018b) Posting of workers: A bad deal that will harm the functioning of the Single Market for services. Press Release. Brussels, 1 st March.

Caro E, Berntsen L, Lillie N and Wagner I (2015) Posted Migration and Segregation in the European Construction Sector. Journal of Ethnic and Migration Studies 41(10): 16001620.

Cremers J (2006) Free movement of services and equal treatment of workers: The case of construction. Transfer 12(2): 167-181.

Cremers J (2010) Rules on working conditions in Europe: Subordinated to freedom of services? European Journal of Industrial Relations 16(3):293-306.

Cremers J (2011) In Search of Cheap Labour in Europe. Working and Living Conditions of Posted Workers. Brussels: European Institute for Construction Labour Research.

Cremers J (2014) Letter box companies and abuse of the posting rules. ETUI Policy Brief 5: 1-5.

Cremers J (2016a) Construction labour, mobility and non-standard employment. HesaMag 13: 1722

Cremers J (2016b) Economic freedoms and labour standards in the European Union. Transfer 22(2): 149-162

Cremers J, Dølvik JE and Bosch G (2007) Posting of workers in the single market: attempts to prevent social dumping and regime competition in the EU. Industrial Relations Journal 38(6): 524-541.

Danaj S and Sippola M (2015) Organising hyper-mobile transnational construction workers. ETUI Policy Brief 11: 1-5.

De Wispelaere F and Pacolet J (2019) Posting of workers. Report on A1 portable documents issued in 2017. Report. Brussels: European Commission.

Dølvik J and Eldring L (2006) La mobilité des services et le détachement des travailleurs dans l'Europe élargie. Transfer 2(6): 142-147.

Druker J and Dupré I (1998) The Posting of Workers Directive and Employment Regulation in the European Construction Industry. European Journal of Industrial Relations 4(3):309-330

European Commission (2013) Détachement des travailleurs: les garanties de l'Union européenne contre le dumping social. Report. Brussels: European Commission.

European Commission (2016) Impact Assessment. Accompanying the document Proposal for a Directive of the European Parliament and the Council amending Directive 96/71/EC concerning the posting of workers. Report. Brussels: European Commission.

European Parliament and Council of the European Union (2018) Directive (EU) 2018/957 of the European Parliament and of the Council of 28 June 2018 amending Directive 96/71/EC concerning the posting of workers in the framework of the provision of services. Official Journal of the European Union (L173/16), 9th July.

European Trade Union Confederation (2017) Revision of the posting of workers Directive - Justice for workers now depends on MEPs. Press Release, 24th October.

European Trade Union Confederation (2018) Justice at least: equal pay for posted workers. Press Release, 29th May.

Fotinopulos O (Coord.) (2017) Presente y futuro del desplazamiento de trabajadores en el marco de la UE. Barcelona: Atelier.

Jorens Y (2008) Self-employment and bogus self-employment in the European construction industry. Report. Brussels: European Commission.

Krings T (2009) A Race to the Bottom? Trade Unions, EU Enlargement and the Free Movement of Labour. European Journal of Industrial Relations 15(1):49-69

Lalanne S (2011) Desplazamiento de trabajadores, ampliaciones de la Unión Europea y mundialización de los servicios. Revista Internacional del Trabajo 130(3-4): 229-252 
This is a previous version of the manuscript published in European Journal of Industrial Relations, 29 June 2019 - OnlineFirst. https://doi.org/10.1177/0959680119860721

Lillie N (2012) Subcontracting, Posted Migrants and Labour Market Segmentation in Finland. British Journal of Industrial Relations 50(1): 148-167.

Muller F (2014) Face aux abus et contournements, la directive d'exécution de la directive détachement est-elle à la hauteur? Revue de Droit Social 10: 788-801.

Mussche N, Corluy V and Marx I (2018) How posting shapes a hybrid single European labour market. European Journal of Industrial Relations 24(2):113-127.

Páramo Montero P (2015) La nueva Directiva 2014/67/UE sobre el desplazamiento temporal de trabajadores. Trabajo y Derecho 3: 52-70

Riesco-Sanz A, García López J and Maira Vidal M (2018) Desplazamiento de trabajadores en la UE. El caso del transporte por carretera. Albacete: Bomarzo.

Vitols S (2018) EU Company Mobility Package: Implications For Social Europe. Social Europe, 11th May.

Voss E, Faioli M, Lhernould JP and Iudicone F (2016) Posting of Workers Directive - current situation and challenges. Report. Brussels: European Parliament.

Wagner I (2014) Rule Enactment in a Pan-European Labour Market: Transnational Posted Work in the German Construction Sector. British Journal of Industrial Relations 53(4): 692-710.

Wagner I and Lillie N (2014) European Integration and the Disembedding of Labour Market Regulation: Transnational Labour Relations at the European Central Bank Construction Site. Journal of Common Market Studies 52(2): 403-419.

Woolfson Ch and Sommers J (2006) Labour Mobility in Construction: European Implications of the Laval un Partneri Dispute with Swedish Labour. European Journal of Industrial Relations 12(1):49-68

\section{Author biographies}

Alberto Riesco-Sanz is associate professor at the University Complutense of Madrid, Spain

Jorge García López is associate professor at the University of Castilla-La Mancha, Spain

María del Mar Maira Vidal is associate professor at the University Complutense of Madrid, Spain 